\title{
Pengaruh Pemberian Pupuk Organik Bokashi Dan Pupuk Npk Phonska Terhadap Pertumbuhan Dan Produksi Tanaman Jahe Putih Besar (Zingiber officinale)
}

\section{Effect of Giving Bokashi Organic Fertilizer and Phonska Npk Fertilizer on Growth and Production of Large White Ginger (Zingiber officinale) Plants}

\author{
Ignasius Daung ${ }^{1}$, Suroto $^{2}$ \\ 1 Alumni Program Studi Agroteknologi, Fakultas Pertanian, Universitas Widya Gama Mahakam Jl. KH. Wahid \\ Hasyim, Sempaja, Samarinda, Kalimantan Timur, Indonesia \\ 2 Tenaga Pendidik Program Studi Agroteknologi, Fakultas Pertanian, Universitas Widya Gama Mahakam Jl. \\ KH. Wahid Hasyim, Sempaja, Samarinda, Kalimantan Timur, Indonesia \\ Diterima : 6 September 2019 Disetujui : 31 Desember 2019
}

Email : ignasiusdaung@gmail.com, surotohs.65@gmail.com

\begin{abstract}
The purpose of this study was to determine the effect and interaction of Giving Bokashi Organic Fertilizer and NPK Phonska Fertilizer on Growth and Production of Large White Ginger Plants. The study was conducted for 5 months, starting in January 2018 until June 2018 starting from the preparation of planting media, nurseries, planting, to data collection. The location of this study was carried out in the experimental garden Faculty of Agriculture, Widya Gama Mahakam University Samarinda at. K.H. Washid Hasyim. The study was arranged in a $4 \times 3$ factorial Randomized Block Design (RBD) and repeated 4 times. The first factor is the Bokashi organic fertilizer (B) consisting of 4 levels, namely: BO (control), B1 (200 g / polybag), B2 (400 g / polybag), and B3 (600 g / polybag). The second factor is NPK Phonska (P) fertilizer consisting of 3 levels, namely: PO (control), $P 1$ ( $30 \mathrm{~g} /$ polybag), and $P 2(40 \mathrm{~g} /$ polybag). The results showed that the treatment of Bokashi organic fertilizer and NPK Phonska fertilizer had a very significant effect on all parameters of observation, while the interaction of the two did not significantly affect all parameters of observation. In general, a dose of $400 \mathrm{~g}$ of Bokashi organic fertilizer for growth and production of large white ginger plants produces the best treatment, and a dose of $30 \mathrm{~g}$ of NPK Phonska fertilizer for growth and production of large white ginger plants produces the best treatment.
\end{abstract}

Keywords: Bokashi Organic Fertilizer, Phonska NPK Fertilizer, Large White Ginger

\section{PENDAHULUAN}

Tanaman jahe sudah terkenal sebagai obat dan minuman penghangat. Jahe merupakan tanaman obat berupa tumbuhan rumpun berbatang semu. Jahe termasuk dalam family (Zingiberaceae), seperti temulawak (Curcuma xanthorrizha), temu hitam (Curcuma aeruginosa), kunyit (Curcuma domestica), kencur (Kaempferia galanga), lengkuas (Languas galanga) dan lain-lain (Setyawan, 2015). Di Indonesia jahe merupakan jenis tanaman herbal yang telah banyak digunakan, hal ini terlihat pada olahan jahe yang bisa dinikmati sebagai minuman penghangat disaat cuaca dingin. Sebagai tanaman herbal, jahe menyimpan macammacam zat yang baik bagi tubuh seperti pencegahan timbulnya kanker, mengatasi masalah pernafasan, melancarkan percernaan, mengatasi memar dan rasa nyeri, oleh karena jahe memiliki banyak manfaat dan keuntungan, serta mudah didalam pengolahan, maka banyak masyarakat Indonesia menanam jahe di berbagai daerah/wilayah. Sebagai salah satu komoditas perkebunan yang sangat dibutuhkan oleh masyarakat terutama sebagai bahan rempah-rempah dan obat-obatan tradisional, jahe mempunyai prospek pemasaran yang cukup baik untuk dikembangkan. Dewasa ini jahe telah menjadi salah satu komoditas ekspor yang permintaannya cukup tinggi dengan harga yang cukup tinggi dibandingkan dengan biaya produksi. Kendala yang ditemui oleh para eksportir adalah pasokan jahe dari sentrasentra produksi tidak mencukupi dibandingkan dengan pesanan yang diterima. Adapun negara-negara tujuan ekspor adalah Amerika Serikat, Belanda, Uni Emirat Arab, Pakistan, Jepang, Hongkong. Bahkan, 
Hongkong yang tidak mengembangkan jahe juga telah mengekspor manisan jahe yang telah diolah dari jahe yang diimpor dari Indonesia. (Setyawan, 2015).

Prospek tanaman jahe sangat baik melihat banyaknya manfaat yang dimiliki oleh tanaman ini. Rimpang jahe dapat digunakan sebagai bumbu masak, pemberi aroma dan rasa pada makanan seperti roti, kue, biskuit, kembang gula dan berbagai minuman. Jahe juga dapat digunakan, minyak wangi, industri jamu tradisional, diolah menjadi asinan jahe, dibuat acar, lalap, bandrek, sekoteng dan sirup. Manfaat tanaman jahe secara pharmakologi antara lain adalah sebagai karminatif (peluruh perut), anti muntah, pereda kejang, anti pengerasan pembuluh darah, peluruh keringat, anti inflamasi, anti mikroba dan parasit, anti piretik, anti rematik, serta merangsang pengeluaran getah lambung dan getah empedu. (Anonim, 2008).

Keberhasilan produksi suatu tanaman sangat ditentukan dengan unsur hara yang cukup. Tanaman membutuhkan unsur hara untuk melakukan proses metabolisme, terutama pada masa vegetatif. kebutuhan akan unsur hara dapat dilakukan dengan cara pemupukan menggunakan pupuk organik maupun pupuk anorganik. Pupuk organik mengandung unsur hara makro yang rendah tetapi juga mengandung unsur mikro dalam jumlah cukup yang sangat diperlukan untuk pertumbuhan tanaman karena mempengaruhi sifat fisik tanah, sifat kimia, dan sifat biologis tanah, juga mencegah erosi dan mengurangi terjadinya keretakan tanah. (Mulyani, 2008).

Pupuk organik bokashi adalah salah satu pupuk organik yang telah berkontribusi banyak terhadap sektor pertanian. Selain menjaga kesuburan tanah dan sebagai pakan ternak, pupuk bokashi bisa menstabilkan hara di dalam tanah serta tentunya ramah terhadap lingkungan. Pembuatan pupuk bokashi dapat memanfaatkan limbah organik yang berada di sekitar. (Arifin, 2007).

Pupuk organik bokashi memiliki keunggulan yaitu mengandung unsur hara

\section{HASIL DAN PEMBAHASAN}

Hasil sidik ragam menunjukkan bahwa perlakuan pupuk Organik Bokashi (B) dan pupuk NPK Phonska (P) berpengaruh sangat makro dan mikro yang lengkap, memiliki kandungan hara yang tinggi dari pupuk kompos, dapat memperbaiki struktur tanah dan dapat meningkatkan pertumbuhan dan produksi tanaman. Penggunaan pupuk anorganik juga diperlukan untuk memacu pertumbuhan tanaman. Pupuk anorganik terdiri dari pupuk tunggal dan pupuk majemuk. Pupuk majemuk merupakan pupuk campuran yang umumnya mengandung lebih dari satu macam unsur hara. Dengan satu kali pemberian pupuk dapat mencakup beberapa unsur, sehingga lebih efisien dibandingkan pupuk tunggal. Kelebihan lain dari penggunaan pupuk majemuk yaitu pupuk NPK phonska yaitu menghemat waktu, tenaga dan biaya. (Hardjowigeno, 2007).

\section{BAHAN DAN METODE}

Bahan yang digunakan dalam penelitian antara lain : rimpang jahe putih besar dari pasar segiri, pupuk organik bokashi dari petani dan pupuk NPK Phonska. Penelitian dilakukan selama 5 bulan, mulai bulan Januari 2018 sampai dengan Juni 2018 terhitung mulai dari persiapan media tanam, pembibitan, penanaman, hingga pengambilan data. Lokasi penelitian ini dilaksanakan di Kebun Percobaan Fakultas Pertanian Universitas Widya Gama Mahakam Jl. K. H. Wahid Hasyim. Penelitian ini disusun dalam Rancangan Acak Kelompok (RAK) dengan analisis faktorial 4 × 3 dan ulangan sebanyak 4 kali. Faktor pertama adalah pupuk organik Bokashi (B) terdiri dari 4 taraf yaitu ; $b_{0}=$ control, $b_{1}=200 \mathrm{~g} /$ polybag, $b_{2}=400 \mathrm{~g} /$ polybag dan $b_{3}=600 \mathrm{~g} /$ polybag. Faktor kedua adalah pupuk NPK Phonska (P) terdiri dari 3 taraf yaitu : $\mathrm{p}_{0}=$ kontrol, $\mathrm{p}_{1}=30$ $\mathrm{g} /$ polybag dan $\mathrm{p}_{2} \quad=40 \mathrm{~g} /$ polybag. Pelaksanaan Penelitian meliputi ; pembibitan, persiapan tempat penelitian, analisis tanah, persiapan media tanam, perlakuan pupuk bokashi, penanaman, perlakuan pupuk npk phonska, pemeliharaan, pemanenan dan pengambilan data

nyata terhadap semua parameter pengamatan. Sedangkan interaksi keduanya tidak berpengaruh nyata terhadap semua parameter pengamatan. Rekapitulasi data penelitian dapat dilihat pada tabel 1. 
Tabel 1.. Rekapitulasi Data Hasil Penelitian Pengaruh Pupuk Organik Bokashi dan Pupuk NPK Phonska Terhadap Pertumbuhan dan Prodı inaman Jahe Putih Besar (Zingiber officinale)

\begin{tabular}{|c|c|c|c|c|c|c|}
\hline \multirow[t]{2}{*}{ Perlakuan } & \multicolumn{3}{|c|}{ Tinggi Tanamwa (un) } & \multirow{2}{*}{$\begin{array}{c}\text { Jumlah } \\
\text { Anakan } \\
\text { (Anakan) } \\
120 \text { HST }\end{array}$} & \multirow{2}{*}{$\begin{array}{c}\text { Berat } \\
\text { Rimpang } \\
(\mathrm{g}) \\
120 \mathrm{HST}\end{array}$} & \multirow{2}{*}{$\begin{array}{c}\text { Jumlah } \\
\text { Rimpang } \\
120 \text { HST }\end{array}$} \\
\hline & $60 \mathrm{HST}$ & $90 \mathrm{HST}$ & $120 \mathrm{HST}$ & & & \\
\hline Bokashi (B) & ** & ** & *** & ** & *** & ** \\
\hline $\mathrm{b}_{0}$ & $11,83 \mathrm{~b}$ & $21,58 \mathrm{~b}$ & $33,33 \mathrm{~b}$ & $7,17 \mathrm{c}$ & $65,75 \mathrm{c}$ & $2,33 \mathrm{~b}$ \\
\hline $\mathrm{b}_{1}$ & $15,08 \mathrm{a}$ & $25,58 \mathrm{~b}$ & $39,42 \mathrm{ab}$ & $10,25 \mathrm{~b}$ & $118,67 \mathrm{~b}$ & $2,83 \mathrm{~b}$ \\
\hline$b_{2}$ & $17,00 \mathrm{a}$ & $31,17 \mathrm{a}$ & $45,92 \mathrm{a}$ & $13,58 \mathrm{a}$ & $155,25 \mathrm{ab}$ & $3,83 \mathrm{a}$ \\
\hline $\mathrm{b}_{3}$ & $16,58 \mathrm{a}$ & $30,50 \mathrm{a}$ & $44,33 \mathrm{a}$ & $14,75 \mathrm{a}$ & $159,58 \mathrm{a}$ & $4,17 \mathrm{a}$ \\
\hline NPK Phonska (P) & $\operatorname{tn}$ & tn & $*$ & $* *$ & * & $* *$ \\
\hline $\mathrm{p}_{0}$ & 15,13 & 26,50 & $36,38 \mathrm{~b}$ & $9,44 \mathrm{~b}$ & $97,38 \mathrm{~b}$ & $2,75 \mathrm{~b}$ \\
\hline $\mathrm{p}_{1}$ & 15,88 & 28,38 & $43,13 \mathrm{a}$ & $11,88 \mathrm{a}$ & $147,50 \mathrm{a}$ & $3,69 \mathrm{a}$ \\
\hline $\mathrm{p}_{2}$ & 14,38 & 26,75 & $42,75 \mathrm{a}$ & $13,00 \mathrm{a}$ & $129,56 \mathrm{ab}$ & $4,50 \mathrm{a}$ \\
\hline Interaksi $(\mathrm{BxP})$ & tn & tn & tn & tn & tn & tn \\
\hline $\mathrm{b}_{0} \mathrm{p}_{0}$ & 13,50 & 22,00 & 30,25 & 6,75 & 81,50 & 2,50 \\
\hline $\mathrm{b}_{0} \mathrm{p}_{1}$ & 12,50 & 23,25 & 35,75 & 7,25 & 74,00 & 2,50 \\
\hline $\mathrm{b}_{0} \mathrm{p}_{2}$ & 9,50 & 19,50 & 34,00 & 7,50 & 41,75 & 2,00 \\
\hline $\mathrm{b}_{1} \mathrm{p}_{0}$ & 14,25 & 23,05 & 32,00 & 8,25 & 74,00 & 2,00 \\
\hline$b_{1} p_{1}$ & 15,50 & 27,75 & 43,50 & 10,50 & 129,25 & 3,00 \\
\hline $\mathrm{b}_{1} \mathrm{p}_{2}$ & 15,50 & 25,75 & 42,75 & 12,00 & 152,75 & 3,50 \\
\hline $\mathrm{b}_{2} \mathrm{p}_{0}$ & 16,00 & 29,25 & 42,25 & 10,25 & 97,50 & 2,75 \\
\hline$b_{2} p_{1}$ & 18,75 & 33,50 & 48,75 & 16.00 & 215,25 & 5,00 \\
\hline$b_{2} p_{2}$ & 16,25 & 30,75 & 46,75 & 14,50 & 153,00 & 3,75 \\
\hline $\mathrm{b}_{3} \mathrm{p}_{0}$ & 16,75 & 31,50 & 41,00 & 12,50 & 136,50 & 3,75 \\
\hline$b_{3} p_{1}$ & 16,75 & 29,00 & 44,50 & 13,75 & 171,50 & 4,25 \\
\hline$b_{3} p_{2}$ & 16,25 & 31,00 & 47,50 & 18,00 & 170,75 & 4,50 \\
\hline
\end{tabular}

\section{Pengaruh Pemberian Pupuk Organik Bokashi Terhadap Pertumbuhan dan Produksi Tanaman Jahe Putih Besar}

Berdasarkan hasil sidik ragam menunjukkan bahwa Perlakuan pupuk organik bokashi berpengaruh sangat nyata pada rata-rata tinggi tanaman umur 60 hst, 90 hst dan 120 hst dan berpengaruh sangat nyata pada rata-rata jumlah anakan umur 120 hst. Hal ini diduga karena kandungan unsur hara pupuk bokashi telah terserap secara maksimal oleh tanaman dan telah mencukupi kebutuhan hara untuk pertumbuhan tinggi tanaman dan jumlah anakan sesuai dengan hasil analisis pupuk bokashi bahwa kandungan unsur hara $\mathrm{N}$ yang berfungsi mempercepat pertumbuhan tanaman tergolong sangat tinggi. Dari data hasil analisis tinggi tanaman menunjukkan bahwa laju pertumbuhan tanaman jahe putih besar pada umur 60 hst, 90 hst dan 120 hst mengalami peningkatan tinggi tanaman. Rata-rata tinggi tanaman mengalami kenaikan terbaik pada umur $60 \mathrm{hst}, 90 \mathrm{hst}$ dan $120 \mathrm{hst}$ yaitu pada perlakuan pupuk bokashi $\mathrm{B}_{2}$ (400g/polybag). Sedangkan perlakuan paling rendah terdapat pada dosis bokashi $\mathrm{B}_{0}$ (kontrol). Rata-rata tinggi tanaman pada umur 120 hari yang tertinggi adalah 45,92 $\mathrm{cm}$. Tinggi tersebut telah mencapai rata-rata tinggi tanaman berdasarkan deskripsi tanaman jahe putih besar yaitu antara $12,5-68,5 \mathrm{~cm}$.

Pupuk bokashi berpengaruh sangat nyata yaitu sesuai dengan pendapat (Suwandi 2011) bahwa pupuk bokashi dapat meningkatkan pertumbuhan dan hasil tanaman, memiliki kandungan hara yang tinggi dibanding pupuk kompos dan masa pertumbuhan tanaman relatif cepat. Lebih lanjut Santoso (1998) menyatakan bahwa kandungan hara dalam bokashi lebih tinggi, sehingga periode tumbuh pada tanaman lebih cepat, pengaruh terhadap tanah sempurna, energi yang hilang rendah dan populasi mikroorganisme dalam tanah lebih sempurna. Dari data hasil analisis jumlah anakan menunjukkan bahwa jumlah anakan menunjukaan peningkatan dari setiap taraf/dosis pupuk bokashi yang diberikan. Hasil tertinggi diperoleh dari dosis bokashi $\mathrm{B}_{3}$ (600g/polybag). 
Sedangkan perlakuan paling rendah terdapat pada dosis bokashi $\mathrm{B}_{0}$ (kontrol). Menurut Mugnisjah dan Setiawan (1990) dalam Asrijal (2005), kandungan hara dalam $\mathrm{N}$ dan P yang ada dalam bokashi sangat dibutuhkan dalam pembentukan anakan, seperti pada tanaman kedelai yang membutuhkan banyak $\mathrm{N}$ dalam pertumbuhannya dengan bintil akarnya dapat menfiksasi $\mathrm{N}$ bebas di udara, dengan kondisi pertanaman yang rapat untuk menjaga kelembapan. Kandungan unsur hara N, P dan K yang tersedia dalam jumlah yang cukup bagi tanaman akan medukung pertumbuhan dan perkembangan terutama pada pembentukan tunas, tinggi tanaman dan pertambahan diameter tanaman (Purwati 2013). Muzaniyyah (2009) dalam Sundari (2016) menambahkan kandungan hara yang ada dalam bokashi sangat dibutuhkan untuk pembentukan anakan, dan memungkinkan pertumbuhan dan perkembangan vegetatif yang lebih baik .

Berdasarkan hasil sidik ragam menunjukkan bahwa perlakuan pupuk bokashi pada umur 120 hst menunjukkan pengaruh yang sangat nyata pada rata-rata berat rimpang dan rata-rata jumlah rimpang. Pupuk bokashi perpengaruh sangat nyata terhadap berat rimpang dan jumlah rimpang diduga bahwa pupuk bokashi telah memperbaiki struktur hara tanah yang dapat meningkatkan daya serap air, hara bagi tanaman dan menyediakan hara yang cukup bagi tanaman sesuai dengan hasil analisis kandungan $\mathrm{C}$ organik yang tergolong sangat tinggi. C-organik merupakan penyangga biologis tanah yang mampu menyeimbangkan hara dalam tanah dan menyediakan unsur hara bagi tanaman secara efisien sehingga berpengaruh sangat nyata terhadap berat rimpang dan jumlah rimpang. Dari data hasil analisis berat rimpang menunjukkan bahwa pada setiap taraf/dosis pupuk mengalami peningkatan berat. Rata-rata berat rimpang mengalami kenaikan terbaik pada perlakuan pupuk bokashi $\mathrm{B}_{3}$ (600g/polybag). Sedangkan perlakuan paling rendah terdapat pada dosis bokashi $\mathrm{B}_{0}$ (kontrol). Kemudian rata-rata jumlah rimpang terbaik terdapat pada perlakuan pupuk bokashi $\mathrm{B}_{3} \quad(600 \mathrm{~g} / \mathrm{polybag})$ sedangkan yang terendah terdapat pada perlakuan pupuk bokashi $\mathrm{B}_{0}$ (kontrol). Menurut Dexter (1988) dalam Arinong (2005), menyatakan bahwa bahan organik dalam tanah selain menambah hara dalam tanah, juga dapat memperbaiki struktur tanah sehingga aerasi tanah menjadi baik, density buruk tanah menjadi lebih rendah yang memungkinkan akar lebih berkembang, sehingga volume akar menjadi lebih besar dan kemamuan menyerap hara juga menjadi lebih besar. Volume akar dan sistem perakaran yang baik sangat mendukung pertumbuhan vegetatif tanaman, seperti tinggi tanaman. Berkaitan dengan hal tersebut bokashi juga meningkatkan aktivitas mikroorganisme tanah yang sangat membantu dalam proses perombakan bahan organik, sehingga hara menjadi tersedia dan penyerapan unsur hara yang dibutuhkan oleh tanaman menjadi meningkat dan memungkinkan tanaman mengalami pertumbuhan dan perkembangan vegetatif yang lebih baik.

\section{Pengaruh Pemberian Pupuk NPK Phonska Terhadap Pertumbuhan dan Produksi Tanaman Jahe Putih Besar}

Hasil sidik ragam menunjukkan bahwa perlakuan pupuk NPK Phonska tidak berpengaruh nyata terhadap rata-rata tinggi tanaman pada umur 60 hst dan 90 hst, namun berpengaruh nyata terhadap rata-rata tinggi tanaman pada umur 120 hst dan perlakuan pupuk NPK Phonska berpengaruh sangat nyata terhadap rata-rata jumlah anakan pada umur $120 \mathrm{hst}$. Pupuk tidak berpengaruh nyata diduga karena pupuk yang diberikan belum diserap seluruhnya oleh tanaman dan juga pemberian pupuk yang diaplikasikan 30 hari setelah tanam sehinga proses penyerapan pupuknya lambat. Sesuai dengan pendapat Sutejo (2008), pemupukan tidak akan berpengaruh terhadap perkembangan daun, batang, dan akar apabila pupuk yang diberikan belum diserap seluruhnya oleh tanaman. Disamping itu bahwa apa yang terdapat dalam tubuh tanaman sangat berhubungan dengan pertumbuhannya. Pertumbuhan tanaman akan berlangsung baik apabila kadar unsur hara yang terkandung dalam tanah tempat tumbuhnya masih baik. Dari data hasil analisis tinggi tanaman umur 60 hst dan 90 hst menunjukkan bahwa tinggi tanaman tidak bertambah secara signifikan sedangkan pada umur 120 hst menunjukan bahwa tinggi tanaman bertambah secara signifikan. Kemudian pada data hasil analisis jumlah anakan menunjukkan bahwa jumlah anakan menunjukan peningkatan dari setiap taraf/dosis pupuk bokashi yang diberikan. Hasil tertinggi diperoleh dari dosis NPK Phonska $\mathrm{P}_{2}$ (40g/polybag). Sedangkan perlakuan paling rendah terdapat pada dosis NPK Phonska $\mathrm{P}_{0}$ (kontrol). Rata-rata tinggi tanaman pada umur 120 hari yang tertinggi adalah $43,13 \mathrm{~cm}$. Tinggi tersebut telah mencapai rata-rata tinggi tanaman berdasarkan deskripsi tanaman jahe putih besar yaitu antara 12,5 - 68,5 cm. Pupuk berpengaruh 
nyata pada umur 120 hst diduga karena pupuk yang diberikan telah terserap oleh tanaman, sehingga berpengaruh terhadap pertambahan tinggi tanaman pada umur 120 hst. Hal tersebut sesuai dengan Peranan utama nitrogen bagi tanaman adalah untuk merangsang pertumbuhan daun, batang, cabang. Nitrogen berperan penting dalam pembentukan hijau daun yang berguna dalam proses fotosintesis. (Lingga, 2007). Menurut Anneahira (2013), keseimbangan unsur hara yang ideal yaitu unsur hara yang ditambahkan untuk melengkapi unsur hara yang telah tersedia dalam tanah hingga jumlah nitrogen $(\mathrm{N})$, fosfor $(\mathrm{P})$, dan kalium $(\mathrm{K})$ yang tersedia untuk tanaman menjadi tepat, sehingga menghasilkan pertumbuhan tanaman menjadi baik. Pupuk anorganik adalah pupuk yang berasal dari bahan mineral yang telah diubah melalui proses produksi sehingga menjadi senyawa kimia yang mudah diserap tanaman salah satunya adalah pupuk NPK Phonska.

Hasil sidik ragam menunjukkan bahwa perlakuan pupuk NPK Phonska berpengaruh nyata terhadap rata-rata berat rimpang pada umur 120 hst dan Perlakuan pupuk NPK Phonska berpengaruh sangat nyata terhadap rata-rata jumlah rimpang pada umur 120 hst Perlakuan pupuk NPK Phonska berpengaruh sangat nyata terhadap rata-rata berat rimpang dan jumlah rimpang. Hal ini diduga karena pupuk dapat diserap oleh tanaman dan digunakan untuk meningkatkan berat rimpang dan jumlah rimpang. Dari data hasil analisis berat rimpang menunjukkan bahwa pada setiap taraf/dosis pupuk mengalami peningkatan berat. Rata-rata berat rimpang mengalami kenaikan terbaik pada perlakuan pupuk NPK Phonska $\mathrm{P}_{1}$ (30g/polybag). Sedangkan perlakuan paling rendah terdapat pada dosis NPK Phonska $\mathrm{P}_{0}$ (kontrol). Kemudian rata-rata jumlah rimpang terbaik terdapat pada perlakuan pupuk NPK Phonska $\mathrm{P}_{1} \quad$ (30g/polybag) sedangkan yang terendah terdapat pada perlakuan pupuk NPK Phonska $\mathrm{P}_{0}$ (kontrol). Menurut (Lingga 2007), Fospor (P) merupakan unsur hara makro yang sangat penting, sangat berpengaruh bagi pertumbuhan dan peningkatan hasil tanaman karena merupakan bagian inti sel, merangsang pertumbuhan akar dan tanaman muda menjadi dewasa, memprcepat pembungaan dan pemasakan buah, biji atau gabah, penyusunan lemak dan protein.

\section{Interaksi Pupuk Bokashi dan Pupuk NPK Phonska Terhadap Pertumbuhan dan Produksi Tanaman Jahe Putih Besar}

Hasil sidik ragam menunjukkan bahwa pupuk bokashi dan pupuk NPK phonska tidak berpengaruh nyata terhadap semua variabel penelitian yaitu tinggi tanaman, jumlah anakan, berat rimpang dan jumlah rimpang. Tidak adanya pengaruh nyata ini karena perlakuan berbagai taraf pupuk bokashi dan pupuk NPK phonska tidak terdapat hubungan saling mempengaruhi, kedua faktor perlakuan tersebut bertindak bebas satu sama lainnya. Hal ini sesuai dengan pendapat steel dan torie (1993), apabila interaksi antara perlakuan yang satu dengan yang lain tidak berbeda nyata, maka dapat disimpulkan bahwa faktor-faktor tersebut bertindak bebas satu sama lain, pengaruh sederhana suatu faktor sama pada semua taraf faktor lainnya.

\section{KESIMPULAN}

1. Pemberian pupuk bokashi berpengaruh sangat nyata terhadap tinggi tanaman, jumlah anakan, berat rimpang, jumlah rimpang. Perlakuan terbaik adalah pemberian pupuk bokashi dengan dosis $400 \mathrm{~g}\left(\mathrm{~B}_{2}\right)$.

2. Pemberian pupuk NPK phonska berpengaruh nyata terhadap tinggi tanaman dan berat rimpang serta berpengaruh sangat nyata terhadap jumlah anakan dan jumlah rimpang pada umur 120 hst. Perlakuan terbaik adalah pemberian pupuk NPK phonska dengan dosis $30 \mathrm{~g}\left(\mathrm{P}_{1}\right)$.

3. Interaksi pupuk bokashi dan NPK phonska tidak berpengaruh nyata terhadap semua parameter.

\section{DAFTAR PUSTAKA}

Anneahira, 2013. Pupuk NPK Phonska. Petrokimia Gersik, Semarang.

Arifin, Z. 2007. Bokashi (bahan organik kaya sumber hayati). Balai Teknologi Pertanian UPTD Pertanian. Malang.

Arinong, 2005. Aplikasi Berbagai Pupuk Organik pada Tanaman Kedelai di Lahan Kering. Jurnal sains \& Teknologi, Agustus 2005, Vol.5 No. 2: 65-72.

Asrijal, 2005. Penggunaan Bokashi Eceng Gondok pada System Pertanaman Tunggal dan Tumpang Sari Padi Gogo dan Kedelai. 
Jurnal sains \& Teknologi, april 2005, Vol. 5 No. 1: 27-36.

Hardjowigeno, S. 2007 Ilmu Tanah. Akademika Pressindo, Jakarta.

Lingga, P. 2007. Petunjuk Penggunaan Pupuk. Penebar Swadaya, Jakarta.

Mulyani, M. 2008. Pupuk dan Cara Pemupukan. Rineka Cipta, Jakarta

Purwati, 2013. Pertumbuhan Bibit Karet (Hevea braciliensis L) Asal Okulasi Pada Pemberian Bokashi dan Pupuk Organik Cair Bintang Kuda Laut. Jurnal Agrifor. Vol $12 \quad$ No1 2013. http://ejurnal.untag-smd.ac.id.

Santoso, B. 1998. Pupuk Bokashi. Kanisius, Yogyakarta
Setyawan, B. 2015. Peluang Usaha Budidaya Jahe. Pustaka Baru Press, Yogyakarta.

Steel, R. G. D. And Torie, J. H. 1993. Principles and Procedur of Statistic (Terjemahan Bambang Sumantri, Prinsip dan Prosedur Statistika). Gramedia, Jakarta.

Sundari, D. 2016. Laporan Praktikum Budidaya Tanaman Lahan Marginal. http://www.academia.edu.com (diakses tanggal 23 May 2018).

Sutejo. 2008. Pupuk dan Cara Pemupukan. Rineka cipta, Jakarta

Suwandi, 2011. Jenis-jenis Bokashi dan Keunggulannya. Yogyakarta 